\title{
Effects of economic globalization and trade on forest transitions: Evidence from 76 developing countries
}

\author{
by Lingchao $\mathrm{Li}^{1}$, Jinlong Liu², Baodong Cheng ${ }^{1}{ }^{*}$, Ashwini Chhatre ${ }^{3}$, Jiayun Dong ${ }^{4}$ and Wenyuan Liang ${ }^{2}$
}

\begin{abstract}
Current forest recovery efforts in developing countries are different from previous efforts in developed countries, especially since the rise of economic globalization in the 1980s. Therefore, forest transition theory should now consider factors relating to industrialization, urbanization, and globalization. While previous studies have mainly focused on the variable trade of primary sector products, this study applies a more holistic research perspective and discusses, more widely, the links between trade, adjustment of trade structure, FDI, and forest transition. The results suggest that the total export value has a significant negative effect on forest area and volume, while the percentage of non-primary products has a significant positive impact on forest volume and density in the 76 developing countries studied. These results indicate that a country or region may improve the forest resource conditions by upgrading the export structure through the development of export-oriented manufacturing and service industries during the process of global industrial restructuring. This demonstrates the need to consider the overall global economic situation of a country when exploring the effects of economic globalization on forest transitions. In addition, this study attempts to address extant concerns regarding the quality of forest transitions by moving beyond the analysis of forest coverage to explore changes in both forest area and forest volume.
\end{abstract}

Keywords: forest transition; reforestation; economic globalization; trade

\section{RÉSUMÉ}

Présentement, les efforts consacrés à la régénération forestière dans les pays en voie de développement diffèrent de ceux que les pays développés y consacraient auparavant en raison surtout de lavènement de la mondialisation économique au cours des années ' 80 . Cest pourquoi la théorie sur la transition forestière devrait maintenant tenir compte des facteurs liés à l'industrialisation, à l'urbanisation et à la mondialisation. Si les études précédentes ont surtout porté sur le commerce changeant pour les produits du secteur primaire, cette étude adopte une approche plus holistique et traite de façon plus globale des liens entre le commerce, les changements à la structure commerciale, l'IDE et la transition forestière. Les résultats laissent voir qu'une hausse de la valeur totale des exportations se traduit par une baisse significative de la surface des forêts et le volume forestier alors que l'augmentation du pourcentage de produits transformés influence positivement le volume et la densité forestière dans les 76 pays en voie de développent faisant l’objet de cette étude. Ces résultats laissent entrevoir qu'un pays ou une région pourrait améliorer létat de ses ressources forestières si elle modernisait sa structure d'exportation en favorisant la croissance d'industries manufacturières et de services en marge une restructuration industrielle globale. De là l'importance de considérer l'ensemble de la situation économique d'un pays lorsqu’on veut connaître les effets de la mondialisation économique sur la transition forestière. Enfin, cette étude tente une réflexion sur les préoccupations courantes sur la qualité de la transition forestière en allant au-delà de l'analyse du couvert forestier pour s'intéresser à la surface des forêts et au volume forestier.

Mots-clés: transition forestière; reboisement; mondialisation économique; commerce

\section{Introduction}

Land changes are widely considered a major driver of global environmental change. In particular, the most significant form of land-use change is conversion from forest land to crop and pastoral land, which raises concerns about habitat conservation, carbon sequestration, and global ecosystem services (Lambin and Meyfroidt 2011). However, while forest destruction continues in many parts of the world, an opposite trend has emerged in some locations (Viña et al. 2016). Such "forest transitions" from loss to gain have been observed in many European and North American countries before the 1980 s and, more recently, in developing economies such as China, Vietnam, Nepal, Costa Rica, and Ecuador (Grau et al. 2003, Mather 2007, Meyfroidt and Lambin 2009).

A careful scrutiny of existing literature suggests that the knowledge of forest transition theory is mainly derived from historical experiences of forest and surrounding human society changes in developed countries against a background of urbanization and industrialization (Mather and Needle 1998). Historically, forest transition is triggered by socioeco-

\footnotetext{
${ }^{1}$ School of Economics and Management, Beijing Forestry University, Beijing, 100083; ${ }^{*}$ corresp: baodongcheng@163.com

${ }^{2}$ Centre of Forestry, Environmental and Resources Policy, Renmin University of China, 100872

${ }^{3}$ Indian School of Business, Gachibowli, Hyderabad 500032 India

${ }^{4}$ Fujian Agriculture and Forestry University of Science and Technology, Fuzhou, 350000
} 
nomic development, when rural populations migrate to urban areas and forest cover expands naturally to abandoned marginal agricultural lands (Rudel et al. 2005). Other important driving factors include agricultural intensification (Mather 1992), national forest protection policy (Wang et al. 2004). and socio-economic institutions (David Barton Bray 2005, Barbier et al. 2010), which usually act simultaneously and are regulated by feedback mechanisms (Kastner et al. 2011).

Over the last few decades, the rapid evolution of economic globalization has made the understanding of forest transition drivers more difficult since forest management and forest cover changes have become more and more related to the flow of goods, people, and capital that connect local land change to global factors (Geist and Lambin 2002, Meyfroidt et al. 2010). However, the mechanisms of how economic globalization processes influence forest cover changes remain unclear. A few pioneering studies have focused on the factors of international primary product trading (Berlik et al. 2002), emigration (Klooster 2003), remittances (Hecht et al. 2006), and tourism (Kull et al. 2007). The most extensive study was on the effects of agricultural and forestry product trading on forest changes, such those associated with leakage or displacement (Lambin and Meyfroidt 2011).

It is well recognized that the international trade of agricultural and forestry products impact changes in local forest coverage by dislocating the impacts of consumption to distant places (Gan and McCarl 2007). More specifically, when all other factors are constant, net wood imports could lower pressures on domestic forests, while net wood exports could increase them (Kastner et al. 2011). This phenomenon of inadvertently shifting impacts elsewhere is often referred to as "leakage" or "displacement" in the literature (Warman and Nelson 2016). Economic globalization may facilitate nationalscale forest transitions through the displacement of deforestation overseas (Meyfroidt and Lambin 2009), and thus decrease the regional and global environmental benefits of policies and schemes aimed at conserving local forest ecosystems (Meyfroidt et al. 2010).

Another important factor for the international wood and agricultural trade that is closely related to leakage or displacement effects is foreign direct investment (FDI) which has received relatively little academic attention to date. In general, FDI is believed to promote the development of export-oriented industries in host countries (Markusen and Venables 1999). For example, a recent study documented the landgrabbing effect of primary sector FDI targeting export-oriented food and biofuel production (Zoomers 2010). Leakages occur when countries displace agricultural or forestry production to distant places through primary sector foreign investment in the process of global economic integration (Jorgenson 2008). Over 50 million ha of farmland in Africa was affected by such FDI (Friis and Reenberg 2010).

Although the importance of international trade and foreign investment were recognized in forest transition literature (Walker 2008), and the risk of leakage is now a globally recognized phenomenon (Pfaff and Walker 2010), quantitative analyses have mainly focused on the effect of international trade and investment in the primary sector. However, agricultural and forestry product trading and related primary sector FDI only account for a small fraction of total global trade and related investments ( $\mathrm{Li}$ et al. 2014). The trade structure change and reallocation of manufacturing and service industries worldwide promoted by the spread of FDI should also be taken into account when investigating the effects of economic globalization on forest transitions.

Forest transition studies have so far provided valuable knowledge on the inter-relationship between forest cover and socio-economic systems. However, the accounting of forest cover changes does not measure large differences between forest quality in terms of biodiversity, carbon stocks, and ecosystem services (Perz 2007). We assume that the drivers of forest quantity and quality transitions could be quite different, even within the same region (Li et al. 2014). Further research is needed to integrate forest quantity and quality analyses in one study to reveal and compare different paths to forest quantity and quality transitions.

Compared to developed countries that experienced forest transition, in the main before the 1980s, forest resource dynamics in developing economies tend to be more influenced by the global economic integration process. Considering land changes as part of global open systems, we analyzed the historical association of changes in nations' forest quantity and quality with changes in international trade and adjustment of trade structure, which is associated with the expansion of FDI in 76 developing countries. This study explores the interconnectedness among forest dynamics, local socioeconomic development and global economic integration and contributes to the understanding of the effects of economic globalization on natural resources.

\section{Background}

The rapid development of economic globalization since the 1980s has brought a surge of trade in forest products and has made forest management and forest cover changes more influenced by global factors. According to the FAOSTAT database, the value of trading forest products increased from US $\$ 56.7$ billion in 1980 to US $\$ 231.3$ billion in 2012. We selected and compared nine developing countries: China, India, Vietnam, Brazil, Indonesia, Myanmar, Argentina, Cameroon, and the Central African Republic, to demonstrate more clearly the relationship between historical changes in forest cover and economic globalization. These nine countries are representative as they have significant forest cover, diverse socio-economic conditions, and are on different continents.

Of the nine countries, China, India, and Vietnam experienced forest transitions in the 1980s and 1990s, while the other countries reported net forest loss. China, India, and Vietnam had a dramatic increase in the value of forest product imports (Fig. 1), while the total export value of forest products increased more rapidly in deforestation economies such as Brazil, Indonesia, Myanmar, Cameroon, and the Central African Republic. Argentina is the only exception. The value of forest product imports and exports increased rapidly during the last few decades in Argentina, and import value exceeded export value. The reason for this may be because Argentina was basically a net importer of forest products and the proportion of agricultural products among total exports was relatively high (Fig. 2). This may have had a negative effect on forest cover change. 


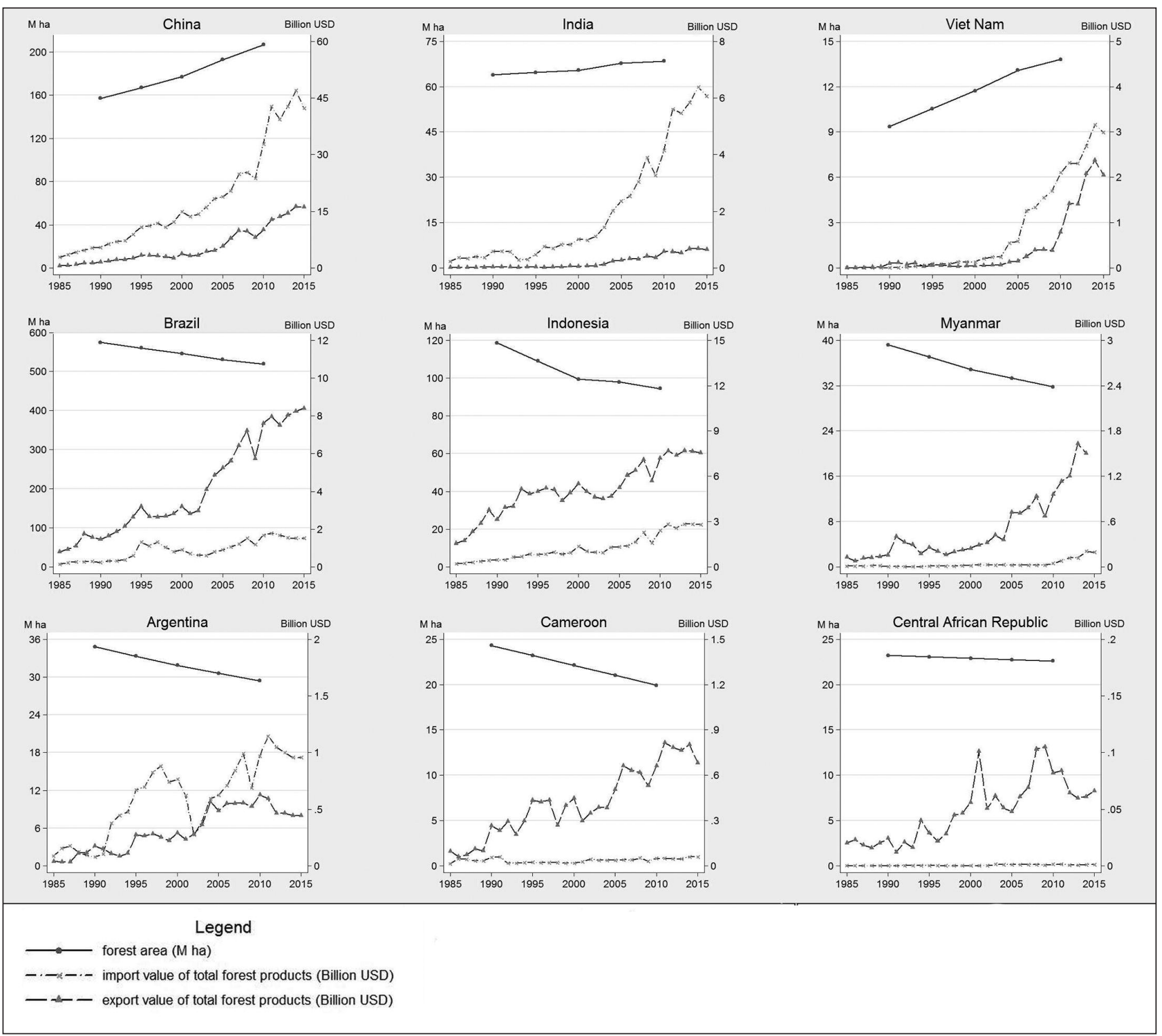

Fig. 1. Historical changes in forest area, import value and export value of total forest products for nine examined countries.

The reallocation of global industries and adjustment of trade structure worldwide is hypothesized to have influenced the dynamics of forest resource change. Fig. 2 shows evidence of the association between change in forest cover and adjustment of trade structure. For countries that experienced forest transitions in the last few decades, the proportion of primary products in total exports declined rapidly after the 1980s. However, Brazil, Indonesia, and Argentina experienced a large decline in forest cover, and the proportion of primary products in total exports fluctuated and remained relatively high during the last few decades. For Myanmar, Cameroon, and the Central African Republic, although the proportion of primary products among total exports shows a declining trend, the absolute value is still high in these deforestation countries (Fig. 2).

During the process of forest transition in developing economies, forestry development and forest resource conservation policies often play an important role (Mather 2007, Li et al. 2016). Large afforestation activities have also been triggered in the private sector by market signals during the last few decades in India, which contributed largely to reforestation (Foster and Rosenzweig 2003). Afforestation activities widely implemented as part of broader forest and natural resource policies or stimulated by forest product prices, are closely related to forest cover increase in the 76 countries (Fig. 3a). In contrast, since the 1980s the scale of afforestation has declined or remained stable in Brazil, Indonesia, Myanmar, Argentina, Cameroon, and the Central African Republic.

Although most developing countries have been influenced by the economic globalization wave, different patterns, including a change of trade volume and trade structure, are seen in different places. An analysis of the 76 developing countries shows that forest area is positively correlated with imports of forest products (Fig. 3b) while forest area is negatively correlated with percentage of primary products in total 


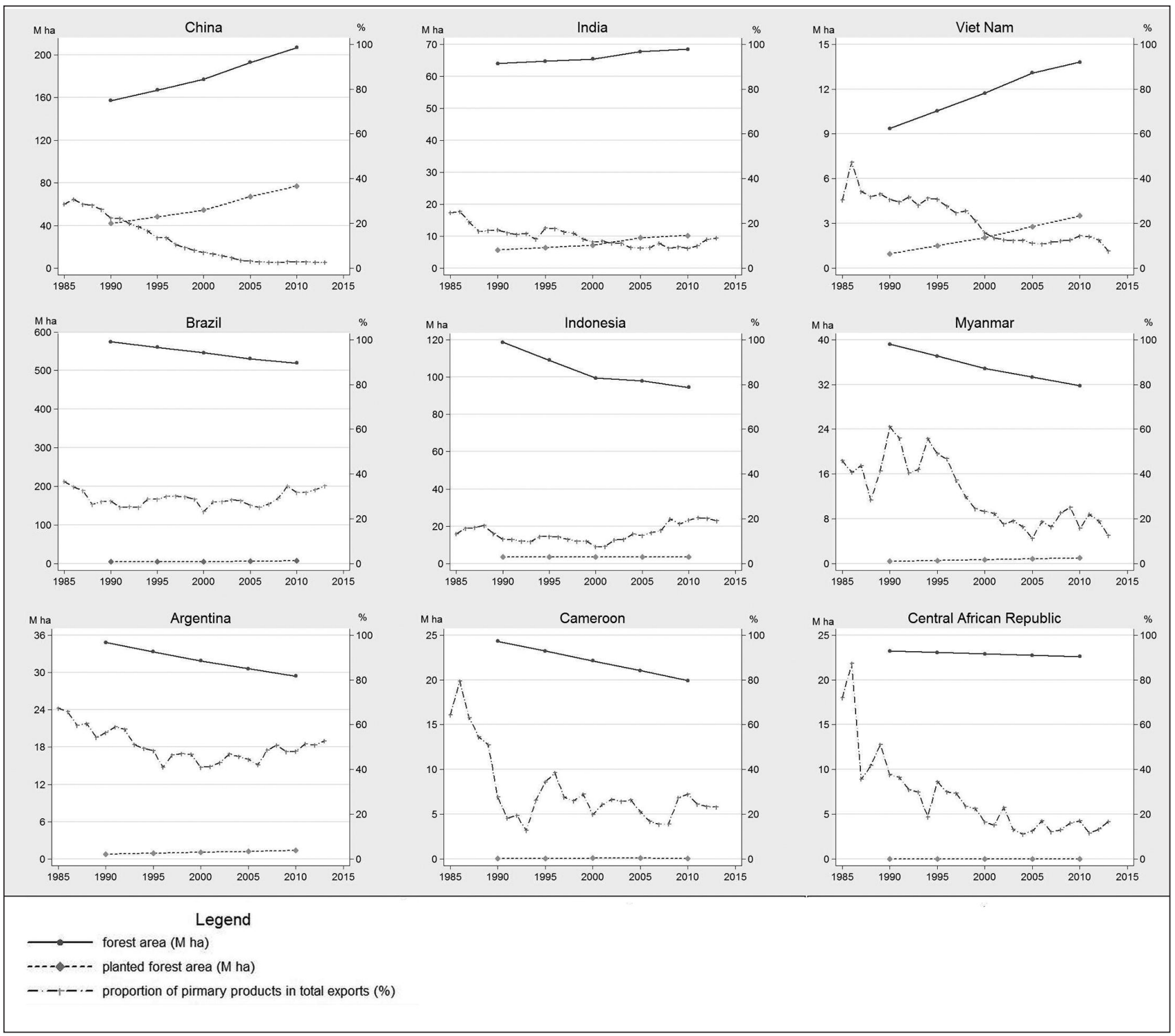

Fig. 2. Historical changes in forest and planted forest area and the proportion of primary products among total exports for nine examined countries.

exports (Fig. 3c). Fig. 3d shows that forest area is positively correlated with exports of non-primary products. These results suggest that, although leakage effects have disadvantages for developing economies that mainly export primary products, the adjustment of trade structure towards non-primary products in the process of economic globalization could have positive effects on natural resource conservation and forest transitions.

Another important feature of the economic globalization wave since the 1980s is the expansion of FDI across the world, which is also closely linked to changes in trade volume and trade structure. We hypothesize that FDI inflows in the manufacturing and service sectors could help host countries develop export-oriented manufacturing and service industries (Hobday 1995) and thus may contribute to upgrading of the export structure and to the reduction of the proportion of primary products among total exports (Li et al. 2014). For instance, after the 1980s, and especially after 1990, FDI inflows and export-oriented manufacturing and service sectors developed rapidly in India and Vietnam, causing a decline in the proportion of primary products (Li et al. 2014). Fig. 4 shows the percentage of non-primary product exports with respect to the percentage of primary sector FDI inflows in 17 of 76 studied countries in 2005. The figure suggests that the percentage of non-primary product exports is negatively correlated with percentage of primary sector FDI inflows.

\section{Materials and Methods Sampling}

This paper focused on developing economies since most developed countries experienced forest transition before the 1980s, and forest cover has remained stable since then. The recent history of forest changes in developing economies however, provides an excellent opportunity to study the ecological consequences of rapid socio-economic, political, technical, and forest management changes associated with eco- 

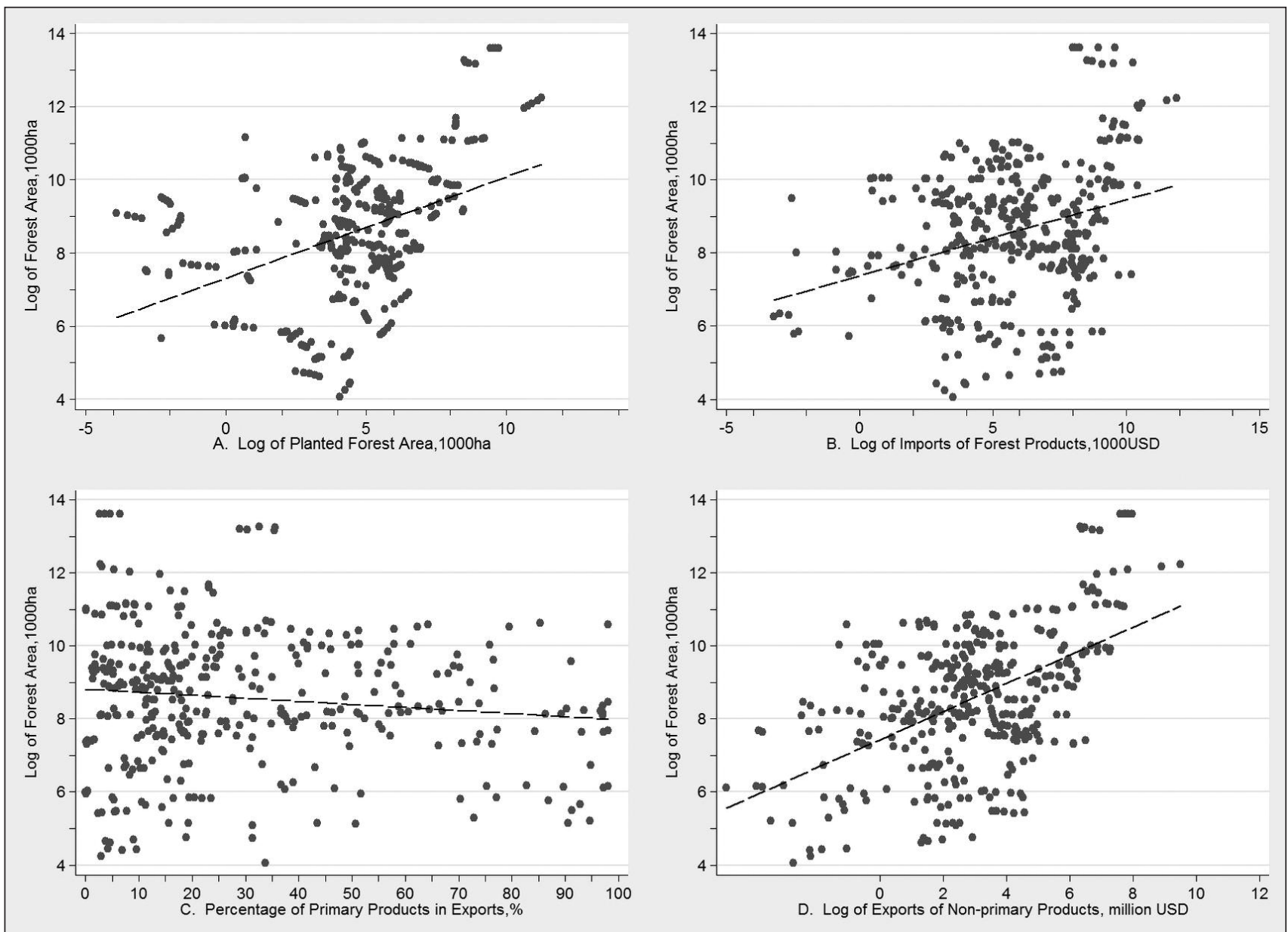

Fig. 3. Patterns of planted forest area, imports of forest products, percentage of primary products among exports, and exports of nonprimary products with respect to total forest area in 76 countries during 1990 and 2010.

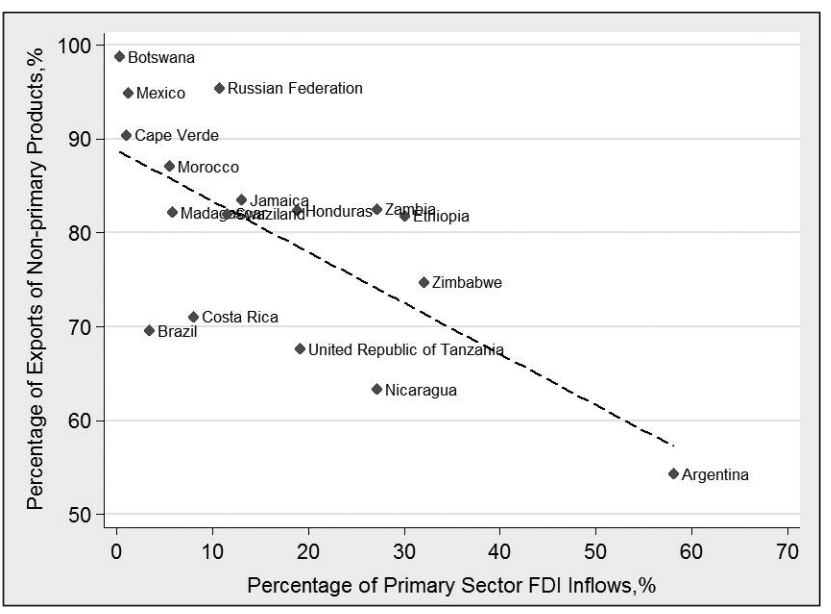

Fig. 4. Patterns of percentage of non-primary product exports with respect to percentage of primary sector FDI inflows in 17 sample countries in 2005.

nomic globalization. Seventy-six developing countries were examined in this study. The other developing countries are excluded from this analysis due to a lack of key forest cover data, a relatively small (less than $50000 \mathrm{ha}$ ) forest area, or stable forest cover over the last few decades.

\section{Dependent variables}

The percentage change of forest area (FA), forest volume $(\mathrm{FV})$, and forest density (FD, calculated as forest volume per area, i.e., FV/FA) were taken as dependent variables in the regression analysis to explore the drivers of both quantity (forest area and forest volume) and quality forest resource changes. Forest quality has diverse and multiple meanings, but can be understood to include biomass, forest health, stand structure, and canopy density. However, subject to data acquisition, we used forest density (FD) as an indicator of forest quality (Kauppi et al. 2006). FD is to some extent related to the carbon sequestration and ecological functions of forests. The data for forest area and forest volume were derived from the FAOSTAT (FAO Statistics Database).

The FAO has conducted forest inventories at ten-year intervals since the 1970s and verifies data provided by countries with field level information gathered from FAO field offices as well as governmental agencies (Bhattarai and Hammig 2001). Most of the previous cross-national analyses rely on these official databases (Mills Busa 2013). Although there are some limits and problems with these statistics, there is no other reliable source of comparable cross-national forest land statistics for developing countries (Bhattarai and Hammig 2001). Details about the advantages and disadvantages of these databases can be found in Mills Busa (2013) and Bhattarai and Hammig (2001). Due to the limited access to forest 
resources data, the longitudinal dataset for the regression analysis covers five periods: 1990, 1995, 2000, 2005 and 2010. The forest resources data for the year 1995 were calculated using linear interpolation.

\section{Independent variables}

The explanatory variable for this analysis is trade and adjustment of trade structure. As a significant component of the FT globalization pathway studies, the effect of trading agricultural and forestry products on forest transition has been recognized in many articles and discussed mainly under "leakage" or "displacement" effects (Zoomers 2010). However, a more remarkable feature of global economic integration during the last few decades has been the rise of trade in manufacturing and service sectors and global industrial restructuring, which have important influences on forest resource changes and have not been fully elucidated (Yirodoe and Nanang 2001).

To measure trade and adjustment of trade structure, we used three indicators: import value of forest products (FIMP); total exports value (EXP); and, percentage of non-primary products in total exports (PNPEXP). In this paper, the FIMP variable is used to capture and reflect the deforestation leakage effects across countries. More importantly, EXP and PNPEXP are incorporated together into the model to help understand more fully the effects of trade and adjustment of trade structure on forest transitions. The data for FIMP were collected from FAOSTAT. According to the definition in FAOSTAT, forest products include roundwood, sawnwood, wood panels, pulp, and paper. The data for total export value and export value in the primary sector were collected from the UNCTADSTAT (UNCTAD Statistics Database). All variables that could be affected by price fluctuations were adjusted by CPI on the base period of 1980 .

\section{Control variables}

Based on forest transition theories, we hypothesize that a range of socio-economic factors could potentially influence the process of forest transition. The first is macroeconomic income factors. The economic development pathway indicates that economic growth may reduce deforestation by creating more non-farm employment opportunities in cities and promoting rural-urban migration, leading to reforestation and an increase in forest cover in rural areas (Templeton and Scherr 1999). The urbanization associated with economic growth also tends to change energy sources from biofuel (i.e., firewood) to hydrocarbons (DeFries and Pandey 2010), thus reducing pressure on forest resources. A number of papers in the literature also discuss the non-linear relationship between forest area and economic growth under the environmental Kuznets Curve (EKC) hypothesis. The EKC for deforestation hypothesizes the existence of an inverted U-shaped relationship between indicators of deforestation and economic growth. However, depending on the geographic regions in the study, the time period of the study and other control variables used in the model, results are mixed (Cropper and Griffiths 1994, Bhattarai and Hammig 2001, Ehrhardt-Martinez et al. 2002, Meyer et al. 2003, Culas 2012). Similar to most previous studies, we take GDP per capita (GDPPC) as a control variable in the regression. A quadratic form of GDP per capita $\left(\mathrm{GDPPC}^{2}\right)$ is also specified in the model to test the EKC relationship.
The second factor is demographics. The inter-relationship between population and land- use changes has received significant attention during the last few decades (Xu et al. 2007). In general, population pressures are considered to be an important proximate driver of deforestation and forest degradation (Mather et al. 1999). However, some other studies have argued that population pressure could stimulate innovations and technical progress in agriculture and enhance agricultural productivity, thus sparing land for reforestation (Koop and Tole 1999). The population factor is also related to the economic development pathway. In this paper we use population density (POPDEN) as another control variable.

The third factor is afforestation. Afforestation activities are directly related to the process of forest transitions. Public and private afforestation activities tend to be associated with the state forest policy pathway and forest scarcity pathway, respectively. In the last few decades, afforestation activities have been wide-spread all over the world, especially in Asian countries such as China, India, and Vietnam (Mather 2007). We use planted forest area (PFA) as a control variable to account for the effects of afforestation. The description of the variables is shown in Table 1.

\section{The empirical models}

Compared to country specific studies, the comparative analysis applied here includes a large variation of socioeconomic structures across countries. This facilitates the identification of the net impact of trade and trade structure adjustment on forest transition. Given the large variation of size across the countries in the sample, it is suggested that the model is estimated by weighted least squares (GLS) to give less weight to the outliers and obtain reliable parameter estimates (Bhattarai and Hammig 2001). Therefore, we estimate the panel-data linear model by using a feasible generalized least squares (FGLS) method, and correct the empirical model for heteroscedasticity and autocorrelation (AR1). The variables are log-transformed to meet the assumptions of the regression model and to make it easier to interpret. Details of the rational and advantages of using FGLS methods can be found in Bhattarai and Hamming (2001). The empirical model we applied is as follows:

$$
\text { 1) } y_{i t}=x_{1 i t} \beta_{1}+x_{2 i t} \beta_{2}+u_{i}+\varepsilon_{i t}
$$

Where y represents the dependent variables, $x_{1}$ is the vector of explanatory variables, $x_{2}$ the vector of control variables, $u_{i}$ the intercept term that represents individual heterogeneity, and $\varepsilon_{i i}$ the disturbing term.

\section{Results}

Table 2 shows the regression results which were statistically significant. The results suggest that the variable total export value (EXP) has significant negative effects on forest area and forest volume. The effects of percentage of non-primary products among total exports (PNPEXP) on forest volume and forest density are significantly positive. These two results have shown the effects of trade and adjustment of trade structure on forest transitions. The findings are consistent with the study on forest transitions in nine Asian countries (Li et al. 2014). The variable GDP per capita (GDPPC) has a significant positive effect on forest area (FA), while it has no signif- 
Table 1. Variable details

\begin{tabular}{|c|c|c|c|}
\hline Variables & Explanation & Unit & Data source \\
\hline \multicolumn{4}{|c|}{ Dependent variables } \\
\hline $\mathrm{FA}$ & Percentage change of forest area & $\%$ & FAO \\
\hline FV & $\begin{array}{l}\text { Percentage change of forest } \\
\text { volume }\end{array}$ & $\%$ & FAO \\
\hline FD & $\begin{array}{l}\text { Percentage change of forest } \\
\text { density }\end{array}$ & $\%$ & FAO \\
\hline \multicolumn{4}{|c|}{ Independent variables } \\
\hline GDPPC & GDP per capita & US\$ & UNCTAD \\
\hline $\mathrm{GDPPC}^{2}$ & GDP per capita squared & US\$ & UNCTAD \\
\hline POPDEN & Population density & People per hectare & FAO, World Bank \\
\hline PFA & Planted forest area & Million hectare & FAO \\
\hline FIMP & Import value of forest products & Million US\$ & FAO \\
\hline EXP & Total export value & Million US\$ & UNCTAD \\
\hline PNPEXP & $\begin{array}{l}\text { Percentage of non-primary } \\
\text { products in total exports }\end{array}$ & $\%$ & FAO, UNCTAD \\
\hline
\end{tabular}

Table 2. Results of regression for forest area, forest volume, and forest density across the 76 countries studied.

\begin{tabular}{|c|c|c|c|}
\hline & $\begin{array}{l}\text { (1) } \\
\text { FA }\end{array}$ & $\begin{array}{l}(2) \\
\text { FV }\end{array}$ & $\begin{array}{l}(3) \\
\text { FD }\end{array}$ \\
\hline GDPPC & $\begin{array}{l}4.146^{* * *} \\
(4.72)\end{array}$ & $\begin{array}{l}1.855 \\
(1.16)\end{array}$ & $\begin{array}{c}0.238 \\
(0.22)\end{array}$ \\
\hline GDPPC2 & $\begin{array}{l}-0.213^{* * *} \\
(-3.71)\end{array}$ & $\begin{array}{l}-0.0339 \\
(-0.33)\end{array}$ & $\begin{array}{c}-0.009 \\
(-0.12)\end{array}$ \\
\hline POPDEN & $\begin{array}{c}0.114 \\
(0.95)\end{array}$ & $\begin{array}{c}0.034 \\
(0.20)\end{array}$ & $\begin{array}{l}-0.282^{* *} \\
(-2.41)\end{array}$ \\
\hline PFA & $\begin{array}{l}0.457^{* * *} \\
(8.27)\end{array}$ & $\begin{array}{l}0.481^{* * *} \\
(5.82)\end{array}$ & $\begin{array}{c}-0.035 \\
(-0.88)\end{array}$ \\
\hline FIMP & $\begin{array}{c}-0.481 \\
(-1.22)\end{array}$ & $\begin{array}{c}-0.688 \\
(-1.15)\end{array}$ & $\begin{array}{c}-0.276 \\
(-0.93)\end{array}$ \\
\hline EXP & $\begin{array}{l}-0.419^{* * *} \\
(-4.62)\end{array}$ & $\begin{array}{l}-0.570^{* * *} \\
(-4.08)\end{array}$ & $\begin{array}{c}-0.025 \\
(-0.36)\end{array}$ \\
\hline PNPEXP & $\begin{array}{r}-0.047 \\
(-0.11)\end{array}$ & $\begin{array}{l}1.371^{* *} \\
(2.16)\end{array}$ & $\begin{array}{l}0.981^{* * *} \\
(2.96)\end{array}$ \\
\hline _cons & $\begin{array}{l}-20.742^{* * *} \\
(-6.16)\end{array}$ & $\begin{array}{l}-13.674^{* *} \\
(-2.26)\end{array}$ & $\begin{array}{c}-0.153 \\
(-0.04)\end{array}$ \\
\hline Wald chi2 & $128.69^{* * *}$ & $79.71^{* * *}$ & $24.13^{* * *}$ \\
\hline$N$ & 304 & 304 & 304 \\
\hline
\end{tabular}

$t$ statistics in parentheses

${ }^{*} p<0.1,{ }^{* *} p<0.05,{ }^{* * *} p<0.01$ icant effect on forest volume (FV) or forest density (FD). The variable GDPPC ${ }^{2}$ has a significant negative effect on forest area (FA), while it has no significant effect on forest volume $(\mathrm{FV})$ or forest density (FD). The results indicate the existence of a U-shaped EKC for forest area. The pattern confirms results from other studies of deforestation in developing countries (Cropper and Griffiths 1994, Koop and Tole 1999). Further, the variable population density (POPDEN) has a negative effect on forest density, while it has no significant effect on forest area or forest volume. The variable planted forest area (PFA) has a significant positive effect on forest area and forest volume but no significant effect on forest density. The result confirms findings on forest transitions from other studies in China, India and Vietnam (Mather 2007, Xu et al. 2007).

\section{Discussion and Conclusions}

Forest transition pathway theories offer us valuable academic insights into drivers and paths to forest transitions from the perspective of socio-economic and political development. Although playing a leading role in many studies, forest transition models are open to further development and refinement in a few important areas, such as regarding the explanation of economic globalization mechanisms and comparison of pathways to forest quantity and quality transitions. This cross-country analysis, situated in a context of economic globalization, aimed to identify forest transition mechanisms that pertain beyond specific countries and to suggest implications for further theoretical explorations of forest transition.

The results from this study suggest that economic growth has positive effects on forest area, but no significant effects on forest volume and forest density in the countries studied. Empirical results also suggest that a U-shaped EKC fits for 
forest area of the 76 countries. The U-shaped curve may imply that although deforestation is prevalent in the studied countries, reforestation programs are greater (Bhattarai and Hammig 2001, Culas 2012). Further, the results on planted forest area (PFA) imply that the most significant drivers of forest cover in the 76 studied countries are afforestation initiatives, while they have no significant effect on forest density. This is probably due to the low stocking volumes of saplings and plantations in general. This may indicate the need for more attention with regard to ecological influences when realizing forest transitions by means of afforestation. Unlike developed countries, reforestation in developing countries can accompany declining forest quality, as reviewed in a study of Mexico (Klooster 2003).

With the rapid development of global economic integration, forest transitions in many countries are associated with the geographic displacement of forest extraction to other countries through trade in agricultural and forest products. Our study also provides evidence for the deforestation leakage hypothesis. With a generally high percentage of primary products in relation to all exports in the studied countries, the variable export value had negative effects on forest area and forest volume.

However, to understand more clearly the relationship between economic globalization and forest transition, we need to consider the overall situation of how individual countries participate in global economic integration, and gain deeper insights into leakage effects by linking forest transition to local socio-economic development influenced by economic globalization processes. Under these circumstances, the development of domestic industries and adjustment of trade structure in the process of global economic integration may have significant effects on changes in forest resources, a topic that has not, as yet, been fully discussed. The regression results show that the variable total export value has significant negative effects on forest area and forest volume, while the percentage of non-primary products in total exports had significant positive effects on forest volume and forest density. Together, these results suggest that, for the 76 countries we studied, the effects of export structure change in relation to forest resources. Against the background of global economic integration, the model presented here hypothesizes that an individual country or region could promote local forest resource preservation when the trade development of the country or region relies more on manufacturing and service industries.

The structural adjustment and relocation of manufacturing and service industries worldwide are closely related to global capital flows. FDI inflows in manufacturing and service sectors could promote the development of export-oriented manufacturing and service industries in developing countries (Markusen and Venables 1999) and thus are expected to upgrade the export structure and reduce the proportion of primary products in total exports. Our study also provides evidence of this hypothesis. Fig. 2 shows that the percentage of non-primary product exports is negatively correlated with the percentage of primary sector FDI inflows in the studied countries. Therefore, unlike the case of negative effects of primary sector FDI inflows on local forest resources, this study implies that FDI inflows in manufacturing and service sectors may have positive effects on forest conservation.
Empirical evidence of links between trade, adjustment of trade structure, FDI, and forest transition can be found in many places across the world. Opening doors to the outside world became China's basic national policy in the mid-1980s, and China increased FDI in the manufacturing sector, especially in coastal areas. The rapid and sustained development of an export-oriented manufacturing economy in the eastern coastal provinces created enormous non-farm work opportunities, which absorbed millions of migrants from inland China, reducing the economic and subsistence pressure on forest resources and facilitating forest regeneration ( $\mathrm{Li}$ et al. 2014). In Puerto Rico, the Dominican Republic, and many other Latin America countries, as socioeconomic globalization extends its effects, an increase in job opportunities in the cities, associated with expanding tourism and manufacturing industries, has stimulated rural-urban migration and forest recovery on abandoned lands in the mountains during the last few decades (García-Barrios et al. 2009).

While previous studies have mostly focused on the variable trade of primary sector products, our study more widely discusses the links between trade, adjustment of trade structure, FDI, and forest transitions. This study presents a more holistic research perspective on the globalization pathway theory of forest transition. Our results indicate that, when exploring the effects of economic globalization on forest transition, we should pay attention to the overall situation of how individual countries participate in economic integration, and to the development and structural adjustment of its industries and trade in the process of economic integration. In addition, this study moves beyond the analysis of forest cover to explore changes in both forest area and forest volume. This allows us to address extant concerns regarding the quality of forest transitions in greater detail. This may constitute an important expansion of forest transition theory.

\section{Acknowledgements}

This research was supported by National Natural Science Foundation of China Grant 71603023 and Beijing Forestry University Grant (2016BLRD04).

\section{References}

Barbier, E.B., J.C. Burgess and A. Grainger. 2010. The forest transition: Towards a more comprehensive theoretical framework. Land use policy 27: 98-107. doi:10.1016/j.landusepol.2009.02.001

Berlik, M.M., D.B. Kittredge and D.R. Foster. 2002. The illusion of preservation: A global environmental argument for the local production of natural resources. J. Biogeogr. 29: 1557-1568. doi:10.1046/j.1365-2699.2002.00768.x

Bhattarai, M. and M. Hammig. 2001. Institutions and the environmental Kuznets Curve for deforestation: A crosscountry analysis for Latin America, Africa and Asia. World Dev. 29: 995-1010. doi:10.1016/S0305-750X(01)00019-5

Cropper, M. and C. Griffiths. 1994. The interaction of population growth and environmental quality. Am. Econ. Rev. 84: 250-254.

Culas, R.J. 2012. REDD and forest transition: Tunneling through the environmental Kuznets curve. Ecol. Econ. 79: 44-51. doi:10.1016/j.ecolecon.2012.04.015

David Barton Bray, P.K. 2005. Deforestation, forest transitions, and institutions for sustainability in Southeastern Mexico, 1900-2000. Environ. Hist. Camb. 11: 195-223.

DeFries, R. and D. Pandey. 2010. Urbanization, the energy ladder and forest transitions in India's emerging economy. Land Use Policy 27: 130-138. doi:10.1016/j.landusepol.2009.07.003 
Ehrhardt-Martinez, K., E.M. Crenshaw and J.C. Jenkins. 2002. Deforestation and the environmental Kuznets curve: A crossnational investigation of intervening mechanisms. Soc. Sci. Q. 83: 226-243. doi:Doi 10.1111/1540-6237.00080

Foster, A.D. and M.R. Rosenzweig. 2003. Economic growth and the rise of forests. Q. J. Econ. 118: 601-637. doi:10.1162/ 003355303321675464

Friis, C. and A. Reenberg. 2010. Land grab in Africa Emerging land system drivers. Glob. L. Proj. Rept. 46.

Gan, J. and B.A. McCarl. 2007. Measuring transnational leakage of forest conservation. Ecol. Econ. 64: 423-432. doi:10.1016/j.ecolecon.2007.02.032

García-Barrios, L., Y.M. Galván-Miyoshi, I.A. Valdivieso-Pérez, O.R. Masera, G. Bocco and J. Vandermeer. 2009. Neotropical Forest Conservation, Agricultural Intensification, and Rural Outmigration: The Mexican Experience. Bioscience 59: 863-873. doi:10.1525/bio.2009.59.10.8

Geist, H.J. and E.F. Lambin. 2002. Proximate causes and underlying driving forces of tropical deforestation. Bioscience 52: 143. doi:10.1641/0006-3568(2002)052[0143:PCAUDF]2.0.CO;2

Grau, H.R., T.M. Aide, J.K. Zimmerman, J.R. Thomlinson, E. Helmer and X. Zou. 2003. The ecological consequences of socioeconomic and land-use changes in post agricultural Puerto Rico. Bioscience 53: 1159. doi:10.1641/0006-3568(2003)053[1159:TECOSA] 2.0.CO;2

Hecht, S.B., S. Kandel, I. Gomes, N. Cuellar and H. Rosa. 2006. Globalization, forest resurgence, and environmental politics in $\mathrm{El}$ Salvador. World Dev. 34: 308-323.

Hobday, M. 1995. Innovation in East Asia: The challenge to Japan. Aldershot, London, U.K.

Jorgenson, A.K. 2008. Structural integration and the trees: An analysis of deforestation in less-developed countries, 1990-2005. Sociol. Q. 49: 503-527. doi:10.1111/j.1533-8525.2008.00126.x

Kastner, T., K.H. Erb and S. Nonhebel. 2011. International wood trade and forest change: A global analysis. Glob. Environ. Chang. 21: 947-956. doi:10.1016/j.gloenvcha.2011.05.003

Kauppi, P.E., J.H. Ausubel, J. Fang, A.S. Mather, R.A. Sedjo and P.E. Waggoner. 2006. Returning forests analyzed with the forest identity. Proc. Natl. Acad. Sci. U. S. A. 103: 17574-9. doi:10.1073/ pnas.0608343103

Klooster, D. 2003. Forest transitions in Mexico: Institutions and forests in a globalized countryside. Prof. Geogr. 55: 227-237. doi:10.1111/0033-0124.5502010

Koop, G. and L. Tole. 1999. Is there an environmental Kuznets curve for deforestation? J. Dev. Econ. 58: 231-244.

Kull, C.A., C.K. Ibrahim and T.C. Meredith. 2007. Tropical forest transitions and globalization: Neo-liberalism, migration, tourism, and international conservation agendas. Soc. Nat. Resour. 20: 723-737. doi:10.1080/08941920701329702

Lambin, E.F. and P. Meyfroidt. 2011. Global land use change, economic globalization, and the looming land scarcity. Proc. Natl. Acad. Sci. U. S. A. 108: 3465-72. doi:10.1073/pnas.1100480108

Li, L., J. Dong and J. Liu. 2016. Research on the impact of policy integration in forest transition. Issues For. Economics 36: 282-288.

Li, L., J. Liu, H. Long, W. de Jong and Y.C. Youn. 2014. Economic globalization, trade and forest transition-the case of nine Asian countries. For. Policy Econ. doi:10.1016/j.forpol.2015.12.006

Markusen, J.R. and A.J. Venables. 1999. Foreign direct investment as a catalyst for industrial development. Eur. Econ. Rev. 43: 335-356. doi:10.1016/S0014-2921(98)00048-8
Mather, A.S. 1992. The forest transition. Area 24: 367-379.

Mather, A.S. 2007. Recent Asian forest transitions in relation to forest transition theory. Int. For. Rev. 9: 491-502. doi:10.1505/ ifor.9.1.491

Mather, A.S. and C.L. Needle. 1998. The forest transition: A theoretical basis. Area 30: 117-124. doi:10.1111/j.1475-4762.1998.tb00055.x Mather, A.S., J. Fairbairn and C.L. Needle. 1999. The course and drivers of the forest transition: The case of France. J. Rural Stud. 15: 65-90.

Meyer, A.L., G.C. van Kooten and S. Wang. 2003. Institutional, social and economic roots of deforestation: A cross-country comparison. Int. For. Rev. 5: 29-37. doi:10.1505/IFOR.5.1.29.17427

Meyfroidt, P. and E.F. Lambin. 2009. Forest transition in Vietnam and displacement of deforestation abroad. Proc. Natl. Acad. Sci. U.S.A. 106: 16139-44. doi:10.1073/pnas.0904942106

Meyfroidt, P., T.K. Rudel and E.F. Lambin. 2010. Forest transitions, trade, and the global displacement of land use. Proc. Natl. Acad. Sci. U.S.A. 107: 20917-22. doi:10.1073/pnas.1014773107

Mills Busa, J.H. 2013. Deforestation beyond borders: Addressing the disparity between production and consumption of global resources. Conserv. Lett. 6: 192-199. doi:10.1111/j.1755-263X. 2012.00304.x

Perz, S.G. 2007. Grand theory and context-specificity in the study of forest dynamics: Forest transition theory and other directions. Prof. Geogr. 59: 105-114. doi:10.1111/j.1467-9272.2007.00594.x

Pfaff, A. and R. Walker. 2010. Regional interdependence and forest "transitions": Substitute deforestation limits the relevance of local reversals. Land Use Policy 27: 119-129. doi:10.1016/j.landusepol.2009.07.010

Rudel, T.K., O.T. Coomes, E. Moran, F. Achard, A. Angelsen, J. Xu and E. Lambin. 2005. Forest transitions: Towards a global understanding of land use change. Glob. Environ. Chang. 15: 23-31. doi:10.1016/j.gloenvcha.2004.11.001

Templeton, S.R. and S.J. Scherr. 1999. Effects of demographic and related microeconomic change on land quality in hills and mountains of developing countries. World Dev. 27: 903-918. doi:10.1016/S0305-750X(99)00037-6

Viña, A., W.J. Mcconnell, H. Yang, Z. Xu and J. Liu. 2016. Effects of conservation policy on China's forest recovery. Sci. Adv. 2: 1-7. doi:10.1126/sciadv. 1500965

Walker, R. 2008. Forest transition: Without complexity, without scale. Prof. Geogr. 60: 136-140. doi:10.1080/00330120701724277

Wang, S., G.C. van Kooten and B. Wilson. 2004. Mosaic of reform: Forest policy in post-1978 China. For. Policy Econ. 6: 71-83. doi:10.1016/S1389-9341(02)00078-3

Warman, R.D. and R.A. Nelson. 2016. Forest conservation, wood production intensification and leakage: An Australian case. Land Use Policy 52: 353-362. doi:10.1016/j.landusepol.2015.12.020

$\mathrm{Xu}$, J., Y. Yang, J. Fox and X. Yang. 2007. Forest transition, its causes and environmental consequences: Empirical evidence from Yunnan of Southwest China. Trop. Ecol. 48: 137-150.

Yirodoe, E.K. and D.M. Nanang. 2001. An economic analysis of the causes of tropical deforestation: Ghana. Am. Agric. Econ. Assoc. Conf. Chicago. 1-27.

Zoomers, A. 2010. Globalisation and the foreignisation of space: Seven processes driving the current global land grab. J. Peasant Stud. 37: 429-447. doi:10.1080/03066151003595325 